\title{
New Testament
}

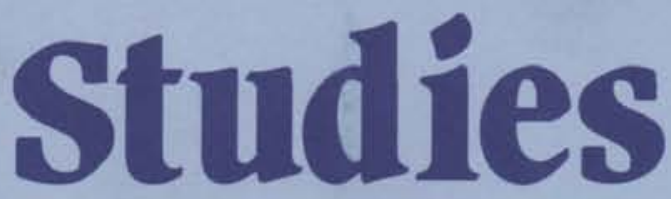

\section{AN INTERNATIONAL JOURNAL \\ PUBLISHED QUARTERLY UNDER THE AUSPICES OF \\ STUDIORUM NOVI TESTAMENTI SOCIETAS}

\section{Volume 39 Number 3 July 1993}

ARTICLES

JosepH A. Frtzmyer, S.J. (Washington DC, USA). The Consecutive Meaning of $\dot{\varepsilon} \phi \hat{\phi}$ in Romans 5.12

Augustin Del Agua (Madrid, Spain). The Narrative of the Transfiguration as a Derashic

Scenification of a Faith Confession (Mark 9.2-8 Par.)

GÉrard Rochass (Montríal, Canada). Jean 7: une construction littéraire dramatique, à la manière d'un scénario

Edvin Larsson (Uppsala, Sweden). Temple-Criticism and the Jewish Heritage: Some Reflexions on Acts 6-7

Cimirers Breytenbach (Berlin, Germany). Zeus und der lebendige Gott: Anmerkungen zu Apostelgeschichte 14.11-17

OTFrite Hofius (Tïbingen, Germany). Das vierte Gottesknechtlied in den Briefen des Neuen Testamentes

Jomn Reumann (Philadelphia, USA). Contributions of the Philippian Community to Paul and to Earliest Christianity

Judrry M. Lreu (London, England). What Was from the Beginning: Scripture and Tradition in the Johannine Epistles

$3^{2 I}-339$

$340-354$

$355-37^{8}$

$379-395$

$396-413$

$414-437$

$43^{8}-457$

$45^{8-477}$

SHORT STUDY

Bruce: W. Longenecker (Durham, England). Hiotı in Romans 3.25: Neglected Evidence for the 'Faithfulness of Christ'? 
EDITORIAL BOARD FOR 1993

EDITOR OF NEW TESTAMENT STUDIES A. J. M. WEDDERBURN (Durham, England)

EDITOR OF THE SNTS MONOGRAPH SERIES M. E. THRALL (Bangor, Wales)

J. M. COURT (Canterbury, England) J. P. MEIER (Washington, DC, USA)

J. DELOBEL (Leuven, Belgium)

D. Heurholm (Oslo, Norway)

J. K. RICHES (Glasgow, Scotland)

C. R. HOLLADAY (Atlanta, Georgia, USA)

v. K. RoBBINs (Atlanta, Georgia, USA)

D.-A. косн (Münster/Westf., Germany)

J. SCHLOSSER (Strasbourg, France)

A. Lindemann (Bethel, Germany)

J. ZUMSTEIN (Zürich, Switzerland)

THE OFFICERS OF THE SOCIETY EX officio:

President of the Society for 1992 93: J. A. FITZMYER, s. J. (Washington DC, USA)

Past-President: E. TROcmé (Strasbourg, France)

President-Elect: M. HENGEL. (Tübingen, Germany)

Secretary: c. M. TUCKETT (Manchester, England)

Assistant Secretary: w. R. TELFORD (Newcastle-upon-Tyne, England)

Treasurer: J. M. couRT (Canterbury, England)

\section{SUBSCRIPTIONS}

New Testament Studies (ISSN $0028-688_{5}$ ) is published quarterly by Cambridge University Press, The Edinburgh Building, Shaftesbury Road, Cambridge CB2 2RU and 40 West 2oth Street, New York, NY 10011-4211. All orders must be accompanied by payment.

Single parts cost $f_{13} .00$ net (US $\$ 27.00$ in the USA, Canada and Mexico), plus postage. Four parts form a volume. The subscription price (which includes postage) of volume 39 is $f 51.00$ net (US $\$ 97.00$ in the USA, Canada and Mexico) for institutions, $£ 34.00$ net (US \$61.0o) for individuals. Students and the retired may subscribe at $\ell_{21.00}$ net (US $\$ 39.00$ in the USA, Canada and Mexico). Japanese prices for institutions (including ASP delivery) are available from Kinokuniya Company Ltd, P.O. Box 55, Chitose, Tokyo.

Members of Studionum. Novi Testamenti Societas receive. New Testament Studies at special terms.

Copies of New Testament Studies for subscribers in the United States of America are sent by air to New York to arrive with minimum delay. Second class postage paid at New York, NY, and at additional mailing offices. Postmaster: send address changes in USA, Canada and Mexico to New Testament Studies, Cambridge University Press, tro, Midland Avenue, Port Chester, New York, NY 105739864 .

\section{COPYING}

This journal is registered with the Copyright Clearance Center, 27 Congress St., Salem, Mass. org7o. Organizations in the USA who are also registered with C.C.C. may therefore copy material (beyond the limits permitted by sections 107 and 108 of US copyright law) subject to payment to C.C.C. of the per-copy fee of $\$ 5.00$. This consent does not extend to multiple copying for promotional or commercial purposes. Code $0028-6885 / 93 \$ 5.00+.00$. Organizations authorized by the Copyright Licensing Agency may also copy material subject to the usual conditions.

ISI Tear Sheet Service, 3501 Market Street, Philadelphia, Pennsylvania 19104, USA, is authorized to supply single copies of separate articles for private use only.

For all other use, permission should be sought from Cambridge or the American Branch of Cambridge University Press. 